\title{
CONFIGURATIONS OF KNOWLEDGE- INTENSIVE ENTREPRENEURIAL ECOSYSTEMS: AN ASSESSMENT OF THE STATE OF SAO PAULO, BRAZIL
}

André Cherubini Alves ${ }^{1}$

Bruno Brandão Fischer ${ }^{2}$

Nicholas Vonortas ${ }^{3}$

Sergio R Queiroz ${ }^{1}$

${ }^{1}$ DPCT/UNICAMP

${ }^{2}$ FCA/UNICAMP

${ }^{3}$ The George Washington University 


\title{
CONFIGURATIONS OF KNOWLEDGE-INTENSIVE ENTREPRENEURIAL ECOSYSTEMS: AN ASSESSMENT OF THE STATE OF SAO PAULO, BRAZIL
}

\begin{abstract}
Knowledge-intensive entrepreneurship is unevenly distributed in geographical space, which is largely attributed to heterogeneous endowments in terms of knowledge, institutions, resources and demand. Nonetheless, specialized literature faces a lack of approaches dealing with the evolutionary dynamics of Entrepreneurial Ecosystems' components. Based on these foundations, we hypothesize that entrepreneurial ecosystems can assume different configurations, i.e., varying combinations of influential dimensions that can generate similar outcomes in terms of entrepreneurial intensity. In order to address this proposal we use Qualitative Comparative Analysis with fuzzy sets to assess city-lvel data from the State of São Paulo, Brazil. The analytical exercise focuses on five dimensions as causal conditions for the emergence of entrepreneurial ecosystems: Science \& Technology, Human Capital, Market Dynamics, Business Dynamics and Infrastructure. Findings underscore the heterogeneous nature of entrepreneurial ecosystems. Nonetheless, a common core is perceived across different configurations, mainly involving the Science \& Technology environment and the local Market Dynamics.
\end{abstract}

Keywords: entrepreneurial ecosystems; evolutionary economic geography; knowledge-intensive entrepreneurship; Brazil.

\section{INTRODUCTION}

Knowledge-intensive entrepreneurship (KIE) represents a socioeconomic phenomenon that drives economic competitiveness and innovative capabilities (Audretsch et al., 2006; Audretsch \& Lehmann, 2005; Ács et al., 2008; Saxenian, 1994). Entrepreneurship has, however, received relatively little attention in studies related to innovation systems' approaches (Ács et al., 2014). The influence of context upon entrepreneurial activity is still often ignored in favor of a focus on individuals and firms (Borissenko \& Boschma, 2016; Autio et al., 2014; Stam \& Spigel, 2016). As a result, we are still some way off a thorough understanding on issues related to the emergence of new technology-based companies and its systemic determinants (Audretsch, 2012).

What is known is that KIE is unevenly distributed in geographical space, which is largely attributed to heterogeneous endowments in terms of knowledge, institutions, resources and demand (Stam, 2009; Feldman, 2014; Isaksen \& Trippl, 2017). As a consequence we observe a spiky geography of economic activities (Florida, 2005; Rodríguez-Pose \& Crescenzi, 2008). In addition, evidence suggests that the impacts of entrepreneurial activity can be mainly felt at the regional level (Ács \& Armington, 2004), placing Entrepreneurial Ecosystems (EEs) as a key aspect of interest for researchers and policymakers in recent years (Malecki, 2011; Audretsch \& Belitski, 2017; Borissenko \& Boschma, 2016) ${ }^{1}$.

These conditions pose fundamental challenges for analysts and policymakers, as one-size-fits-all initiatives and analytical models can be deemed inappropriate for most locations (Nicotra et al., 2017; Stam \& Spigel, 2016). The economic mechanisms that shape evolutionary trends in entrepreneurship are not of a linear nature and they operate differently in distinct locations with varying socioeconomic backgrounds (Ács et al., 2017; Brown \& Mason, 2017; Martin \& Sunley, 2011; Audretsch, 2015; Boschma \& Martin, 2010; Rosenthal \& Strange, 2001). Even in the case of world-renowned ecosystems, success can be reached in fundamentally distinct manners - as Saxenian (1996) illustrated in a comparison between the Silicon Valley and Route 128.

Thus, a simplistic, mechanistic approach to entrepreneurial ecosystems - based on a linear inputoutput logic - is likely to ignore the context-specific traits of regions and their interplay (Feldman, 2001). The combination of these features is what drives the aggregate patterns of firm-level

\footnotetext{
${ }^{1}$ The very concept of entrepreneurial ecosystems encompasses a focus on innovation-driven entrepreneurship (Stam \& Spigel, 2016). Organizadores: Realizadores: 
competitiveness in EEs (Radosevic \& Yoruk, 2013). Nonetheless, specialized literature faces a lack of approaches dealing with the evolutionary dynamics of EEs components (Mack \& Mayer, 2016). Based on these foundations, we hypothesize that entrepreneurial ecosystems can assume different configurations, i.e., varying combinations of influential dimensions that can generate similar outcomes in terms of entrepreneurial intensity. This is a function of distinct evolutionary paths of each location. Accordingly, our research questions can be stated as follows: Are there different configurations of vectors of interest that shape successful entrepreneurial ecosystems?

Drawing from different strands of literature addressing the dynamics of business location we deal with a broad set of variables in order to identify the different foundational patterns behind ecosystems of entrepreneurship. For a concrete case we assess the State of São Paulo, Brazil. We assess KIE using data from PIPE projects, a program funded by FAPESP (the research funding agency of the State of São Paulo) that supports innovative initiatives in small enterprises (resembling in structure and objectives the Small Business Innovation Research - SBIR program in the United States). Our goal is to develop further knowledge on the evolutionary geography of innovation and entrepreneurship in the context of an advanced region in a developing country, acknowledging the substantial discrepancies that these countries present respective to developed economies when it comes to the geography of entrepreneurial activity (Crescenzi \& Rodríguez-Pose, 2012). We expect our research to inform analysts and policymakers with a multidimensional view on the location drivers of start-ups in relatively laggard innovation systems - even though analytical insights can be useful for more advanced nations as well.

After this introductory section, the rest of the article is structured as follows: Section 2 contains the conceptual background of our assessment, as well as the proposal of a workable analytical model for the case of the State of São Paulo. Section 3 debates the state of the literature and the need for a more flexible comprehension of entrepreneurial ecosystems' configurations. Section 4 presents the method and the data used in our approach. Section 5 presents empirical results, and Section 6 closes with concluding remarks, implications and avenues for future research.

\section{KNOWLEDGE-INTENSIVE ENTREPRENEURIAL ECOSYSTEMS}

Regions differ in their respective propensity to establish knowledge-intensive entrepreneurial activity (WEF, 2014). These patterns reinforce themselves throughout time because geographic proximity functions as a fundamental vector for knowledge exchange (Gilbert et al, 2004). In its turn, such interactions among agents largely define firms' innovative capabilities (Fagerberg et al., 2005). These conditions put significant emphasis in the comprehension of local-level context as a determinant for KIE emergence, moving the target beyond the sole understanding of firm-level capabilities (Mason \& Brown, 2014; Ács et al., 2014; Audretsch \& Belitski, 2017).

It is by acknowledging these features of the socioeconomic environment that the Entrepreneurial Ecosystems concept has gained ground in recent years. According to its original definition, EEs represent 'an interconnected group of actors in a local geographic community committed to sustainable development through the support and facilitation of new sustainable ventures' (Cohen, 2006; p. 3). A somewhat similar conceptualization has been offered by Mason and Brown (2014; p. 5) when they refer to EEs as a 'set of interconnected entrepreneurial actors, entrepreneurial organizations, institutions and entrepreneurial processes which formally and informally coalesce to connect, mediate and govern the performance within the local entrepreneurial environment'.

In sum, the underlying rationale of entrepreneurial ecosystems is focused on interactions between economic agents, tangible and intangible factors of production, and how these vectors translate into entrepreneurship within a given location (Ács et al., 2017; Nicotra et al., 2017; Mack \& Mayer, 2016; Stam, 2015). Because of its (eco)systemic character, the productivity of these geographical units is 
affected by the performance of any of their components (Ács et al., 2014). By productivity we understand what Radosevic and Yoruk (2013) call 'entrepreneurial propensity', i.e., the local capacity to generate and exploit innovation-oriented opportunities through the doings of entrepreneurs. In the same vein, Audretsch et al. (2006) make reference to 'entrepreneurship capital', understood as the capacity of local-level institutions fostering entrepreneurial activity.

Based on this literature, and with particular emphasis on the works of Isenberg (2010), and Mason and Brown (2014), we offer a workable model of the entrepreneurial ecosystem concept (Figure 1). Our adaptation follows the basic principles contained in existing frameworks. Some items are dropped because of the lack of available information to address this model empirically at the local-level (citylevel) in the Brazilian context ${ }^{2}$. In this regard, main shortcomings concern dimensions related to culture, venture capital and public policy - although the latter can be indirectly assessed through other elements. Next we address in further detail each of the five dimensions set out in the model.

Figure 1. Knowledge-Intensive Entrepreneurial Ecosystem

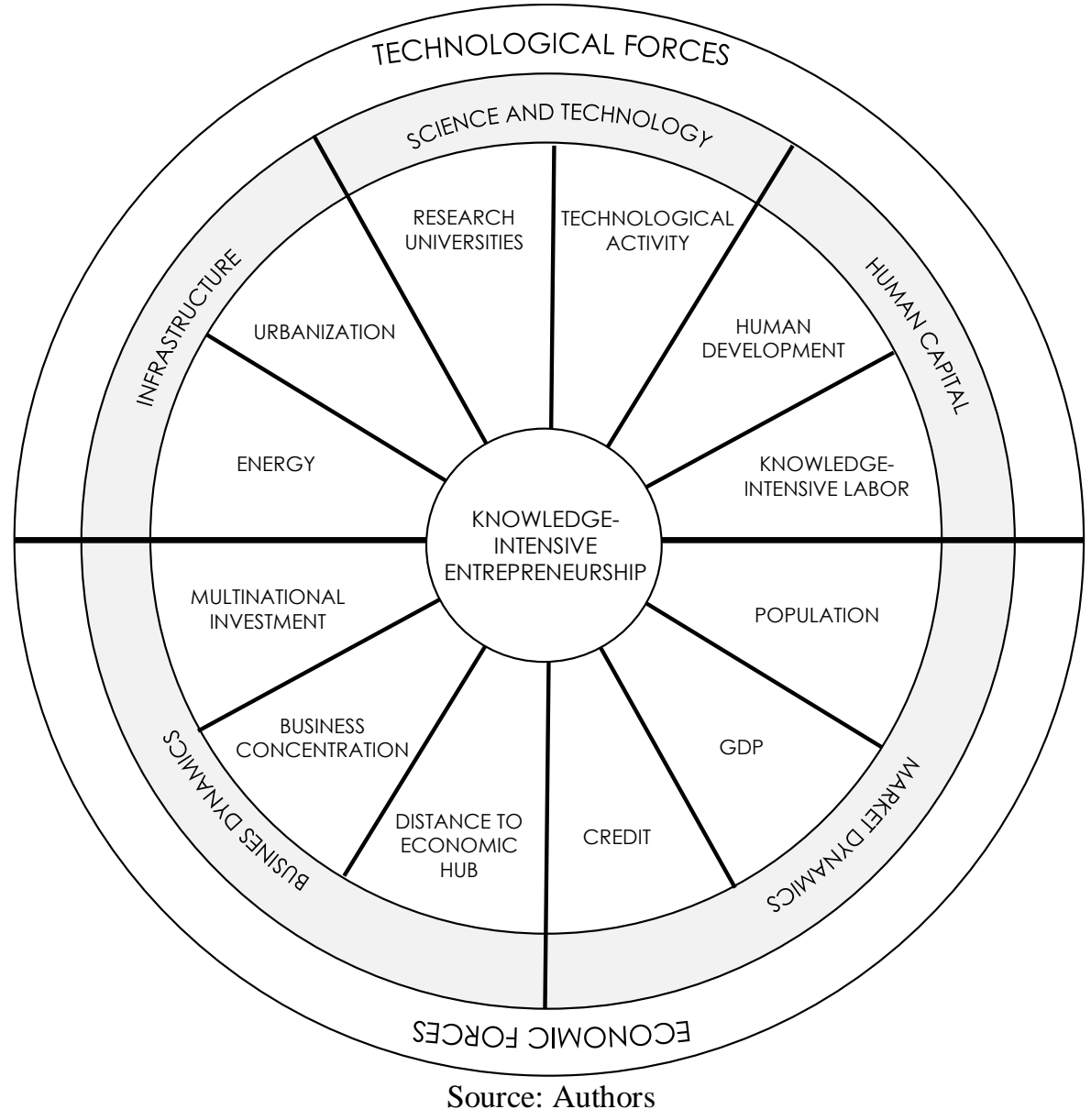

\subsection{Science and Technology}

Amongst the factors related to entrepreneurial location in geographical space, access to a relevant knowledge base stands for a fundamental attribute of interest - even more so for the scrutiny of knowledge-intensive entrepreneurship (Nicotra et al., 2017; Boschma \& Martin, 2010). Affluent

\footnotetext{
${ }^{2}$ Because of the highly local nature of entrepreneurial ecosystems, literature has recognized these units (cities) as the most adequate locus for empirical assessments (Bruns et al., 2017;Audretsch \& Belitski, 2017)
}

$$
\text { Organizadores: Realizadores: }
$$


technological environments tend to facilitate entrepreneurial activity at the local level (Nicotra et al., 2017). In the State of São Paulo, Brazil, city-level patenting activity has demonstrated a strong influence on the emergence of KIE activity (Fischer et al., 2017).

Universities and research institutes are strategic agents within these dynamics (Spigel, 2017; Stam \& Spigel, 2016). These institutions not only contribute to knowledge generation, but they also shape local conditions related to educational attainments of the population, issues of vital importance for the emergence and success of new technology-based ventures (Isaksen \& Trippl, 2017; Dorfman, 1983). Therefore, geographical proximity to research-oriented universities and research centers can be valuable source of knowledge for high-tech entrepreneurial activity (Stam, 2009).

Apart from that, science-based entrepreneurship is significantly related to academic spin-offs (Di Gregorio \& Shane, 2003), a situation that attributes key relevance to the local presence of preeminent universities. Etzkowitz (1998) puts the university and academic researchers as fundamental agents of innovation systems through knowledge transfer and entrepreneurial activities, an issue also raised by Guerrero et al. (2016). This helps explaining why high-tech clusters are often attached to university campus towns (Isaksen \& Trippl, 2017). Fitjar and Rodríguez-Pose (2011) even make a case for regions that lack agglomeration economies (in the sense of large economic structures) but present high relative levels of innovative activity. These regions present a high tendency to create virtuous circles of innovative activity, even in the absence of other relevant drivers of entrepreneurial activity.

\subsection{Human Capital}

Chatterji et al. (2013) state that the key pillars clusters of entrepreneurship are essentially related to human capital. This is incorporated in the general education of the workforce and on the local supply of individuals with entrepreneurial orientation. This feature is widely recognized by literature, be it under the concepts of human capital (Isenberg, 2011; WEF, 2014), worker talent (Spigel, 2017), human resources (Nicotra et al., 2017) or talent pool (Stam \& Spigel, 2016). Illustratively, the ratio of hightech employment often predicts entrepreneurial activity in regions (Motoyama \& Danley, 2012).

In fact, availability of highly skilled labor is a structural precondition for the creation of innovative entrepreneurial systems (Bresnahan et al, 2001). Also, although labor is theoretically considered as a mobile resource, entrepreneurial clusters are more likely to arise wherever professional talent is located or where it can be easily attracted (Dorfman, 1983). Accordingly, Audretsch and Feldman (1996) identified that the propensity to cluster is stronger in industries that rely heavily in new economic knowledge, thus depending to a large degree upon skilled labor. This proximity allows easier access for KIE companies to tap into available human capital and establish knowledge exchange practices with other agents (Storper, 1995).

In addition, entrepreneurial strengths are strongly related to income per capita of individuals (Radosevic \& Yoruk, 2013; Stel et al., 2007). These conditions approximate not only the level of education and capabilities within the pool of individuals, but also the quality of life and overall level of development of regions, fundamental aspects in the location decision of knowledge-intensive entrepreneurs (Florida \& Mellander, 2014).

\subsection{Market Dynamics}

The third dimension of interest in our EE model concerns the Market Dynamics of specific locations. The inclusion of this analytical vector follows one of the key traditions in the assessment of the geography of economic activity (Florida \& Mellander, 2014). When it comes to entrepreneurial activity, large markets can offer increased levels of opportunities (Armington \& Ács, 2002). Isenberg (2010) follows this rationale, including local markets as significant vectors in the formation of entrepreneurial ecosystems - a proposition that finds support in other influential documents on this

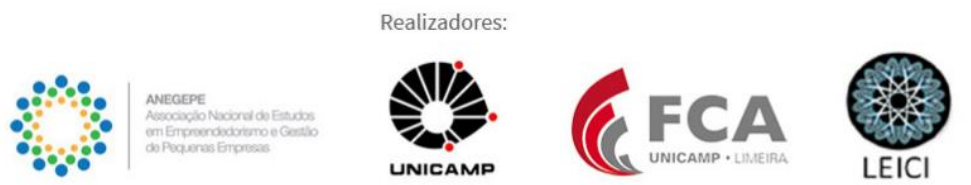


field of analysis (WEF, 2014). Correspondingly, evidence from developed countries suggest that opportunity-driven entrepreneurship tends to be more concentrated in large urban areas (Bosma \& Sternberg, 2014). Also, the size of markets also feeds entrepreneurial endeavors from a different direction: the size of the population is a representation of the pool of potential entrepreneurs in a given location (Stuart \& Sorenson, 2003).

Another issue that falls under our category of market dynamics concerns the economic conditions for available funding for knowledge-intensive entrepreneurs, an aspect that is ubiquitous in entrepreneurial ecosystems approaches (Isenberg, 2010). This is a function of the strategic relevance attributed to credit as a platform for start-ups to operate (Lerner, 2002; Feldman, 2001). Besides private flows of capital, governments can help correcting market failures in financing processes of these incipient ventures, based on the expectation that the introduction of these enterprises can result in substantial social and private gains for economic systems (Lerner, 2002). Considering the Brazilian context, this vector is particularly critical as SMEs in this country find it difficult to have access to funding mechanisms in Brazil due to scarce credit lines (Neto, et al., 2014; Ribeiro \& Carvalho, 2008).

\subsection{Business Dynamics}

Complementarily to the idea of market dynamics we bring a perspective on the business environment -and its intrinsic dynamics - of cities as an influential component of entrepreneurial ecosystems. Here we introduce the importance of aspects related to the level of development of regional economic structures, as well as its attractiveness for investments from incumbent firms.

Firstly, literature recognizes the importance of adjacent firms as an important driver of local competitiveness (Stuart \& Sorenson, 2003). This can take place through either Marshallian (specialization) or Jacobian (diversification) processes (Beaudry \& Schiffauerova, 2009). In any case, positive externalities arise from local clustering of firms. This generates a critical mass of support activities for new companies (Isenberg, 2010; Isaksen \& Trippl, 2017; Storper, 1995). Besides, these incumbent firms can also leverage the growth conditions for new firms (WEF, 2014), providing incentives for new business creation and contributions to start-up firms' survival (Delgado et al., 2010). Within this context, large firms play an important role in setting the stage for the emergence of knowledge-intensive new ventures (Brown \& Mason, 2017). These large companies can leverage overall capabilities in clusters, particularly multinational corporations (Bresnahan et al, 2001), given their key role in the formation of innovation ecosystems (Guimón, 2009). Isaksen and Trippl (2016) refer to this situation as benefits related to thick and diversified regional innovation systems.

An additional item of interest in this analysis concerns the geographical reach of large markets (or core regions) and how the proximity to these economic hubs can exert effects in neighboring areas. This happens because large cities are not only a representation of an agglomeration of people, but they are also associated with the generation of innovative, science-based entrepreneurship (Duranton \& Puga, 2002). In this regard, an 'efficiency gap' exists when comparing peripheral regions to those located close to large markets (Fritsch, 2002; Crescenzi \& Rodríguez-Pose, 2012). This is why hightech clusters of entrepreneurship are prone to be located in core regions (Isaksen \& Trippl, 2017). This situation can be magnified in areas such as the State of São Paulo, provided the presence of a Megahub (WEF, 2018), i.e., an exceptional large city that functions as center for business services, venture capital and corporate demand.

\subsection{Infrastructure}

The third dimension in our model deals with the quality of infrastructure in cities. This is a platform upon which economic activity strongly relies. Infrastructure facilitates urban linkages, labor mobility and knowledge flows (Audretsch et al., 2015). Thus, its impacts as a determinant of formation of 
entrepreneurial ecosystems must be acknowledged (Spigel, 2017; Nicotra et al., 2017; Stuart \& Sorenson, 2003). Also, infrastructural quality can mitigate ambiguous effects associated with large markets' agglomeration diseconomies (Audretsch \& Belitski, 2017) and establish the intensification of relationships among individuals through higher urbanization levels, driving diversification of demand (Stam, 2009). It must be recognized, however, that these urbanization economies - while relevant for entrepreneurial activity - present a marginal contribution to EEs when compared business concentration (outlined in Section 2.2) (Rosenthal \& Strange, 2001).

\section{HETEROGENEOUS CONFIGURATIONS OF ENTREPRENEURIAL ECOSYSTEMS}

Notwithstanding the agreement on the very basic definitions of entrepreneurial ecosystems, there are persistent controversies on causal links within its intrinsic dynamics (Borissenko \& Boschma, 2016). After all, what dimensions of interest really matter for EEs? One of the main issues here concern the potential tautology involved with proposed models based on the reality of some highly preeminent cases (e.g. Feld, 2012; Saxenian, 1994). These expositions - although informative - are developed around an idea of relative stability in the configuration of influential attributes in EEs. On the other hand, researchers have increasingly criticized such formulations, as they lead to one-size-fits-all implications.

Even if the dimensions included in these models are highly inclusive, some of its attributes may be more dominant in some cases than in others (Spigel, 2017), relativizing the importance of EEs' components according to different contexts (Motoyama \& Watkins, 2014). The central argument here is that economic mechanisms shaping evolutionary trends are not of a linear nature, and they operate differently in distinct locations as a function of their historical backgrounds (Boschma \& Martin, 2010). This is why top-down policies to organize clusters of entrepreneurship can be deemed as ineffective (Bresnahan et al, 2001; Chatterji et al, 2013; Dorfman, 1983). Hence, mechanistic approaches to entrepreneurial clusters based on the linear input-output relationships are likely to ignore systemic and context-specific features of regions (Feldman, 2001).

This is the pillar of Evolutionary Economic Geography (EEG). EEG puts emphasis in historical processes related to the generation of knowledge bases and industries at the regional/local level, as well as interaction patterns among agents (Isaksen \& Trippl, 2017). In dealing with the dynamics of entrepreneurial ecosystems, the evolutionary view pinpoints the relevance of pre-existing conditions and assets - such as research institutes and potential entrepreneurs - for ecosystems to emerge (Isaksen, 2016). Accordingly, new science-based firms can be understood as functions of the prior existence of scientific research undertaken by universities and research institutes in a given location (Feldman \& Lendel, 2011).

What we want to add to this debate is a perspective that, because of distinct evolutionary paths, entrepreneurial ecosystems can achieve efficiency (or a successful level of 'entrepreneurial propensity') through different configurations. In other words, the relevance of EEs' dimensions are bounded by location-specific trajectories, thus altering the dynamics of interconnection among actors, institutions and organizations. This leads us to the following research hypothesis:

$H_{1}$. Because of idiosyncratic evolutionary paths, Entrepreneurial Ecosystems can present heterogeneous configurations in terms of relevant drivers without compromising their respective level of entrepreneurial propensity.

Recent literature has dedicated some efforts in a similar direction. Brown and Mason (2017) develop a simplified taxonomy of entrepreneurial ecosystems, based on illustrative cases of 
'embryonic' and 'scale-up' locations. By testing this hypothesis, our goal is to empirically refine these introductory propositions and provide a more nuanced view on the variegated combinations of characteristics that can form a functional $\mathrm{EE}$.

\section{METHODOLOGICAL APPROACH}

The basic source of information concerns data for knowledge-intensive entrepreneurship in the State of São Paulo, Brazil. The grants of the PIPE program are used as a proxy for KIE activity. This program is funded by the Research Foundation of the State of São Paulo (FAPESP) to support innovative initiatives in small enterprises. The program has similar structure and objectives to the Small Business Innovation Research (SBIR) program in the United States. The full dataset includes 1130 grants located in 114 cities across the state allocated during the period 1998-2014. We selected data from 298 cities in the State of São Paulo in order to run comparative models and account for differences in configurations between cities that have received project grants from those that have not received them. This information is supplemented with data on the urban environment, infrastructure, market conditions, and distance from the major economic hub for all the examined cities in the state.

To address our research questions we use Fuzzy-Set Qualitative Comparative Analysis (fsQCA). QCA is a method used to identify configurations or 'recipes' of causal conditions associated with different outcomes. It follows the 'equifinality principle', meaning that multiple paths or solutions can lead to the same outcome (Ragin, 2000). Different from statistical regression analysis, QCA also follows principle of causal complexity, that is, instead of looking at the effect of independent variables into a dependent variable, it accounts for the combination of causal measures to a specific outcome within a property space.

\subsection{Model and Unit of Analysis}

Following the literature review contained in Section 2 of our article and graphically represented in our analytical model (Figure 1), as well as respecting a parsimony principle for fsQCA solutions, the socioeconomic dimensions included in our assessment are described in Table 1. Most variables represent averages of city-level characteristics as proxies of the prevailing economic conditions in the examined cities. This procedure avoids problems related to year-to-year variations, while also controlling for the time span during which projects have started (1998-2014).

Table 1. Variable Description and Sources

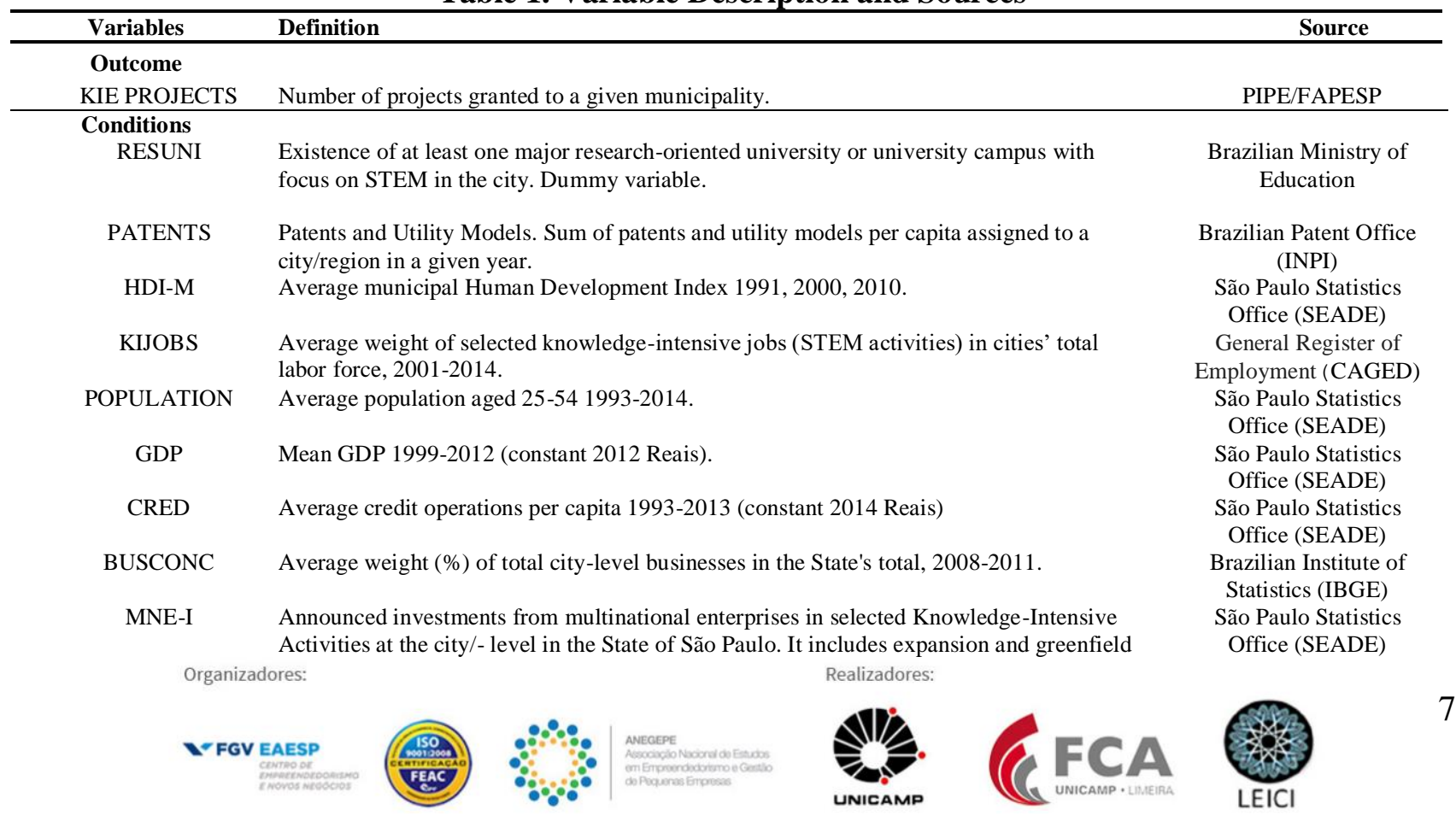


investments. Data represents the average investment for the $2002-2014$ period in millions of USD

PROXCAP Road distance in km from the state capital and economic center, São Paulo.

Google Maps

São Paulo Statistics Office (SEADE) São Paulo Statistics Office (SEADE)

\subsection{Calibration procedures}

Qualitative Comparative Analysis works using the principle of set-theoretic 'membership' using fuzzy-sets. In order to conduct the analysis, variables must be calibrated into the fuzzy sets by defining thresholds (Ragin, 2007). In order to calibrate the fuzzy-sets, we used quartiles (see Appendix 1). The only exception for this rule was the causal condition RESUNI which was a binary variable indicating the presence or absence of a major Research University in the city. For the PROXCAP, quartiles were obtained by using only the cities that have displayed the outcome. For the Outcome variable, a rather flexible threshold was used in order to generate enough diversity in our sample and avoid skewness of the data. Our sample had a total of 298 cities where 114 of these cities had received grants. We chose to set our threshold at 1 in order to include in the set-membership of the innovation ecosystems any city with 3 or more grants.

We used the following set-membership threshold for our outcome variable:

- Above 10 projects (full membership)

- Between 4 to 10 projects (more-in-than-out)

- Between 2 to 4 (more-out-than-in)

- Below 2 (full non-membership)

\subsection{Analysis of Necessary Conditions}

As indicated by Ragin (2000), we ran two sets of analysis: the first one verify if any of our causal conditions could be considered necessary for the Outcome. Conditions are considered necessary when they represent the superset of the outcome, i.e., when the set membership values for the outcome Y are lower than the set membership for a given causal condition (Ragin, 2006). Necessary conditions are verified by using the following formulas for Consistency and Coverage.

$$
\begin{aligned}
\text { Consistency: } \Sigma\left\{\min \left(X_{i}, Y_{i}\right)\right] / \Sigma\left(Y_{i}\right) & \text { equation (1) } \\
\text { Coverage }\left(Y_{i} \leq X_{i}\right): \Sigma\left\{\min \left(X_{i}, Y_{i}\right)\right] / \Sigma\left(X_{i}\right) & \text { equation (2) }
\end{aligned}
$$

According to Ragin (2008, p. 44), "consistency addresses the degree to which instances of the outcome agree in displaying the causal condition to be necessary, while coverage assesses the degree to which instances of the condition are paired with instances of the outcome". Coverage indicates the relevance or importance of a set-theoretic connection. However, necessary conditions are more important the 'more sufficient' they are (Goertz, 2006). This can be verified as the coverage of the conditions $(\mathrm{X})$ decreases in relation to the outcome $(\mathrm{Y})$.

The second test involves the analyses of sufficiency to identify the combinations of conditions that that are in accordance with the presence of KIE activity, thus forming knowledge-intensive entrepreneurial ecosystems. Fuzzy-sets are converted into crisp-sets with value of 1 or 0 if the set membership scores on fuzzy-sets falls above or below the 0.5 . This generates a truth table with the property space of different combinations or configurations of conditions that lead to the outcome ${ }^{3}$ We analyzed the truth table correlating the membership scores of different conditions with intensity of entrepreneurial activity to identify different configurations associated with entrepreneurial ecosystems.

\footnotetext{
${ }^{3}$ The complete truth table is available from the authors upon request.
} Organizadores: 
In this article we present results for the Complex Solution, which provides a general description of different sufficient causal paths that can be observed in cases where the outcome is present.

\section{RESULTS}

Table 3 and Figure 2 show the causal paths for the complex solution (CS) obtained in our analysis, consisting of four paths. The overall consistency of the solution indicated that $85 \%$ of cases displaying the outcome have been captured by the solution paths. As it can be observed, RESUNI, PATENTS, HDIM, POP, BUSCONC, GDP and CRED are present in all paths. These conditions seem to be a shared base for the most relevant EEs. However, differences arise when we focus on the following variables: KIJOBS, PROXCAP, MNE, ENERGY and URB. These results signal the existence of variegated structures in entrepreneurial ecosystems, even though they fundamentally rely on a common core of drivers.

The first path of the complex solution, besides the common conditions, adds KIJOBS, $\sim$ PROXCAP, URB and $\sim$ ENERGY to its configuration. This particular profile of entrepreneurial ecosystems demonstrate high presence of knowledge-intensive jobs, are distant from the main regional economic hub (city of São Paulo), with high levels of urban population and with deficient infrastructure (as indicated by the relatively low per capita consumption of energy). Path 1 seemingly stands for a typical configuration of peripheral entrepreneurial ecosystems. The emblematic case of this group is São Carlos, a small/medium-sized city, far from the State capital, with a strong academic environment and thriving conditions for KIE activity (Fischer et al., 2018). In its turn, the city of Araras presents a very low membership in the outcome, a situation that can be understood as an 'error' as per its inclusion in Path 1 . This city has received only 1 KIE project grant over 20 years. Nonetheless, this case could deserve some attention as it matches the high membership score in all causal conditions within the group.

\section{Table 3. Sufficient combination of conditions for high KIE activity (Complex Solution)}

\begin{tabular}{|c|c|c|c|c|}
\hline Path & Recipe & $\begin{array}{l}\text { raw } \\
\text { coverage }\end{array}$ & $\begin{array}{l}\text { unique } \\
\text { coverage }\end{array}$ & consistency \\
\hline 1 & RESUNI*PATENTS*HDIM*KIJOBS*POP*GDP*CRED*BUSCONC* PROXCAP*URB* ENERGY & 0.20 & 0.10 & 0.82 \\
\hline 2 & RESUNI*PATENTS*HDIM*KIJOBS*POP*GDP*CRED*BUSCONC* MNE* PROXCAP*ENERGY & 0.09 & 0.03 & 0.77 \\
\hline 3 & RESUNI*PATENTS*HDIM*KIJOBS*POP*GDP*CRED*BUSCONC*MNE*PROXCAP*URB & 0.21 & 0.14 & 0.88 \\
\hline \multirow[t]{3}{*}{4} & RESUNI*PATENTS*HDIM* KIJOBS*POP*GDP*CRED*BUSCONC* $\sim$ MNE*PROXCAP*URB* ENERGY & 0.05 & 0.01 & 0.91 \\
\hline & $\begin{array}{ll}2 & \text { Solution coverage }\end{array}$ & 0.39 & & \\
\hline & Solution consistency & 0.85 & & \\
\hline
\end{tabular}

The second path of the complex solution is slightly different from the first with the addition of one variables (Energy) and the absence of another (MNE). Similar to the first path, it has a high presence of knowledge-intensive jobs, far from the main economic hub, urbanized and with high infrastructure, but with low levels of investments from multinational companies. However, differently from Path 1, this group includes a regional economic center, the city of Ribeirão Preto. In any case, this seems to represent an alternative configuration of entrepreneurial ecosystems located outside the geographic reach of the city of São Paulo, consisting of an additional profile of peripheral EE.

The third path of the CS is of high importance given its raw and unique coverage. Besides the common core of EE variables perceived in our sample, this group comprehends cities that are close to the main economic hub and with significant amounts of MNE investment. Also, high levels of urban population are noticed, in line with the agglomeration economies' hypothesis rationale. Path 3 stands for a clear representation of a 'core' entrepreneurial ecosystem. The key cities in this group are São Paulo, Campinas and São José dos Campos. Added to this group are São Bernardo do Campo and Santo André. While these two cities alone do not seem to fit the model because of their low outcome 
in terms of KIE projects, all causal conditions match the ones for the more robust ecosystems in this group. These two cities are industrial districts located within the metropolitan area of São Paulo.

Lastly, Path 4 is composed of one city alone: Santos. This path presents a peculiar configuration, one with the absence of positive influences from KIJOBS, MNE investments and lack of infrastructure. This can be related to local specificities that are not captured by our analysis. For instance, even though the human development index (HDIM) has a positive influence in all of the four paths, it should be noticed that Santos stands above the rest of cities with KIE activity in the State of São Paulo (0.840). Also, being a coastal city, it offers a wide range of amenities that might attract entrepreneurs ${ }^{4}$. In addition, Santos is located close to the city of São Paulo $(72 \mathrm{~km})$, facilitating the connection between new ventures and the support system available in the core region. For this reason, Path 4 can be understood as am 'adjacent' EE.

Figure 2. Configurational Paths of Knowledge Intensive Innovation Ecosystems

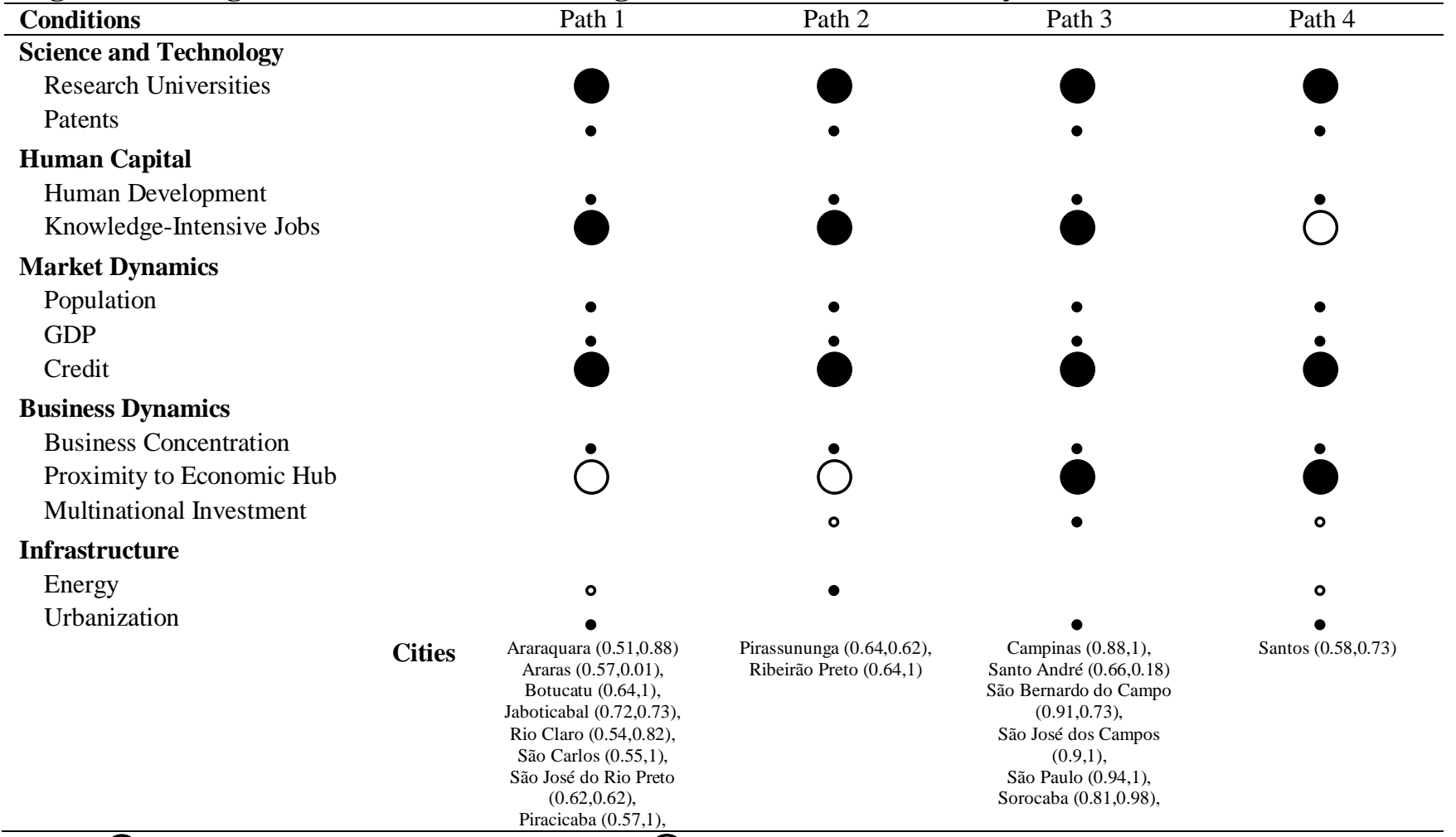

Note: $\bigcirc=$ core causal contributing condition (present); $\bigcirc=$ core causal contributing condition (absent); $\bullet=$ contribution causal conditions (present); $0=$ contribution causal conditions (absent)

Figure 3 presents the geographic distribution of these configurations. The blue marks show the cities that were selected through the construction of the truth table (Table 3 ) above the 0.76 consistency threshold. The green marks present relatively important innovation ecosystems that fell below the consistency threshold of 0.76 . These are a cities that do not present research universities, but have received a significant number of KIE projects. These cities are Mogi das Cruzes, Barueri, Jundiaí, Paulínia and Indaiatuba. While they do not have research universities, they are geographically located inside of a technological corridor near to cities that do have. Thus, we are calling these cities as 'satellite' EEs as they gravitate close to important technological centers.

\footnotetext{
${ }^{4}$ Unfortunately we could collect comprehensive data to test for this dimension. On the importance of amenities for entrepreneurial
} activity, see Florida (2003). 
Figure 3. Mapping KI-Entrepreneurial Ecosystems in the State of SP

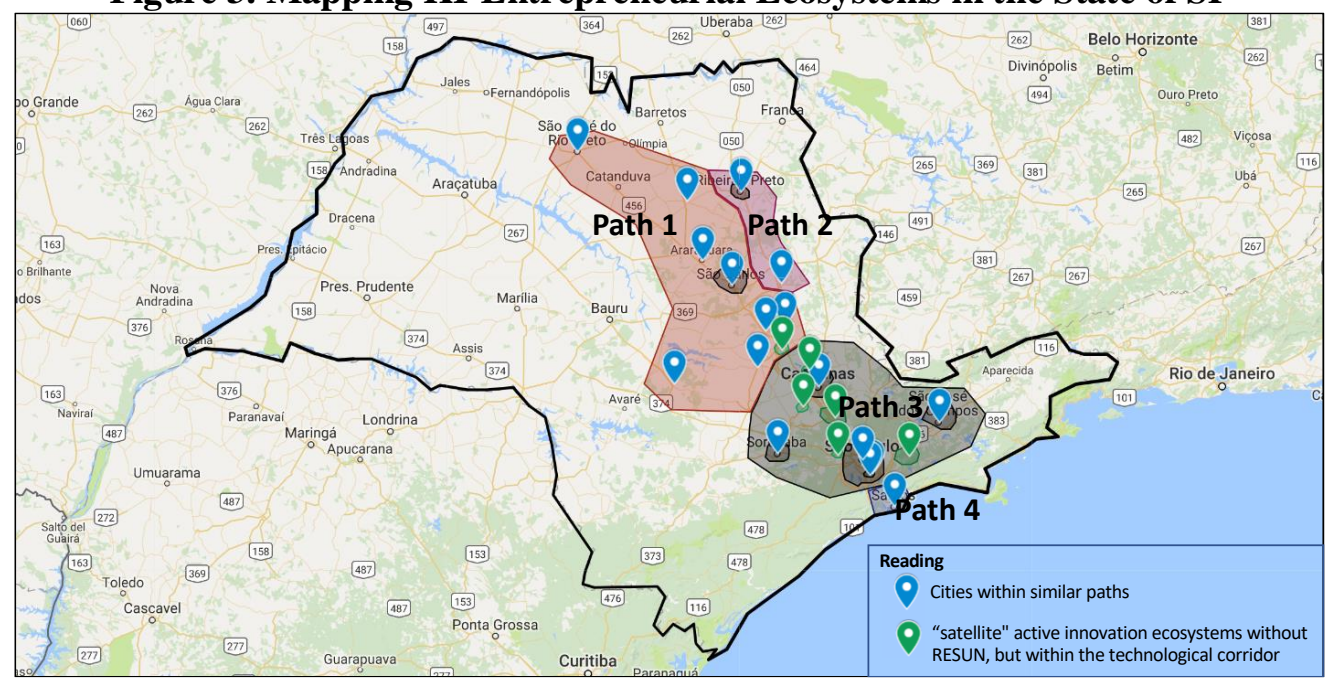

Source: Authors (based on research data)

\section{CONCLUDING REMARKS}

Our empirical assessment highlights the existence of heterogeneous configurations in entrepreneurial ecosystems in the State of São Paulo, Brazil, confirming our research hypothesis. However, a common core of features arise. This provides novel empirical findings that support expectations set by arguments contained in evolutionary economic geography arguments (Borissenko \& Boschma, 2016; Boschma \& Martin, 2010). Also, it highlights a hierarchy of attributes (Spigel, 2017) and a key role played by the knowledge context as a precondition for EEs to prosper (Feldman \& Lendel, 2011).

In this regard, a first dimension of interest concerns Science \& Technology. The existence of preeminent research universities and strong technological activity are key drivers of knowledgeintensive entrepreneurship, as they leverage local stocks of knowledge capital. Local market dynamics (represented by economic size - GDP and population - and credit availability) exerts consistent impacts on cities' propensity to generate KIE activity. The validity of these two dimensions indicate a balance between market and technological forces in the nature of entrepreneurial ecosystems, pinpointing its multifaceted character (Isenberg, 2010; Mason \& Brown, 2014).

The remaining dimensions also presented contributions to the production of relatively successful EEs. This is the case for human development conditions (partially representing the Human Capital dimension) and business concentration (Business Dynamics). For the case of business concentration, this finding provides support for the hypothesis of localization economies, as per the relevant contributions coming from a complementary productive structure (Isaksen \& Trippl, 2017; Delgado et al., 2010). On the other hand, such perspective is not necessarily valid for the specific case of multinational companies - as our related indicator is not part of the common core in EEs' configurations. In this regard, it is important to take into account the distinct patterns of knowledge flows established by these firms within the context of developing countries when compared to advanced nations (Girma, 2005). Surprisingly, the Infrastructure dimension provides contributions rather shaky contributions - in some cases it is positively related to KIE activity, while in others it seems to exert negative impacts. This may be due to the operational variables applied.

Another remarkable result concerns the heterogeneity of influence attributed to the variable PROXCAP. Our results clearly indicate that both core and peripheral regions are capable of establishing prosperous levels of entrepreneurial activity, contrary to propositions stating a loss of 
innovative capability in areas located outside the reach of economic centers (Fritsch, 2002; Crescenzi \& Rodríguez-Pose, 2012). Provided that KIE is associated to increased levels of economic competitiveness, this situation may stand for a long term process of economic convergence, alleviating agglomeration diseconomies involved with exceptionally large metropolitan areas in laggard economies (Henderson, 2002).

The main message arising from our empirical findings is that entrepreneurial ecosystems are diverse in their configurations, and that comprehensive models may fail to address locations' idiosyncrasies. In its turn, this conceptual misfit is likely to lead to inadequate, one-size-fits-all policies and interventions - as it has been the case in several places worldwide, as expressed by the widespread 'next Silicon Valley' speech. By ignoring the local context, these top-down initiatives from policymakers to steer the development of clusters are usually unsuccessful (Martin \& Sunley, 2003). Instead, emphasis should be put in policymakers understanding local/regional idiosyncrasies in terms of innovation and entrepreneurial dynamics (Isaksen \& Trippl, 2017). The government role in fostering entrepreneurial ecosystems must be one of facilitating (not leading) the preexistent local strengths and capabilities, respecting cultural and institutional contexts, heterogeneity of firms and technologies, and designing regulatory reforms that can foster individual initiatives (Isenberg, 2010).

Notwithstanding, while these are fundamental preconditions for adequate policies to emerge, our results also pinpoint the existence of necessary circumstances for KIE to thrive. This may be unfortunate news for several locations, as many of the influential drivers take a long time to mature and they are outside the reach of direct interference of policymakers. This is the case for most of the indicators that are part of the EEs common core in our analysis. Perhaps more challenging than that is the fact that several of these indicators can be taken as endogenous respective to knowledge-intensive entrepreneurship.

We expect our research to contribute to the debate on the evolutionary character of entrepreneurial ecosystems. Further testing of the propositions contained in this article, along with the use of different variables and dimensions, could provide more in-depth insights into this inquiry. Also, analyzing evidence from countries and regions in different stages of development is desirable, as some traits identified in our sample shall not hold in other contexts. Such appraisals are needed in order to overcome limitations to our methodological approach, mostly concerning the sample of knowledgeintensive entrepreneurs (based solely on data from one specific funding program) and the parameters used to identify successful cases of entrepreneurial ecosystems. This discussion based on empirical evidence is of utmost relevance for advancing the quality of entrepreneurial policymaking and maximize benefits that may emerge from these new ventures.

\section{REFERENCES}

Ács, Z., \& Armington, C. (2004). Employment growth and entrepreneurial activity in cities. Regional Studies, 38(8), 911-927.

Ács, Z., Autio, E., \& Szerb, L. (2014). National systems of entrepreneurship: measurement issues and policy implications. Research Policy, 43(3), 47-494.

Ács, Z., Stam, E., Audretsch, D., \& O’Connor, A. (2017). The lineages of the entrepreneurial ecosystem approach. Small Business Economics, 49(1), 1-10.

Armington, C., \& Ács, Z. J. (2002). The determinants of regional variation in new firm formation. Regional Studies, 36(1), 33-45.

Audretsch, D. B., \& Lehmann, E. E. (2005). Does the knowledge spillover theory of entrepreneurship hold for regions? Research Policy, 34(8), 1191-1202.

Audretsch, D. (2012). Entrepreneurship research. Management Decision, 50(5), 755-764. 
Audretsch, D. (2015). Everything in its place: Entrepreneurship and the Strategic Management of Cities, regions, and states. Oxford: Oxford University Press.

Audretsch, D., \& Belitski, M. (2017). Entrepreneurial ecosystems in cities: establishing the framework conditions. Journal of Technology Transfer, 42(5), 1030-1051.

Audretsch, D., \& Feldman, M. (1996). R\&D spillovers and the geography of innovation and production. The American Economic Review, 86(3), 630-640.

Audretsch, D. B., Heger, D., \& Veith, T. (2015). Infrastructure and entrepreneurship. Small Business Economics, 44(2), 219-230.

Audretsch, D., Keilbach, M., \& Lehmann, E. (2006). Entrepreneurship and Economic Growth. New York: Oxford University Press.

Audretsch, D. B., \& Lehmann, E. E. (2005). Does the knowledge spillover theory of entrepreneurship hold for regions? Research Policy, 34(8), 1191-1202.

Autio, E., Kenney, M., Mustar, P., Siegel, D., \& Wright, M. (2014). Entrepreneurial innovation: the importance of context. Research Policy, 43(7), 1097-1108.

Beaudry, C., \& Schiffauerova, A. (2009). Who's right, Marshall or Jacobs? The localization versus urbanization debate. Research Policy, 38(2), 318-337.

Borissenko, Y., \& Boschma, R. (2016). A critical review of entrepreneurial ecosystems: towards a future research agenda. [Papers in Evolutionary Economic Geography \#16.30]. Utrecht University - Urban \& Regional Research Centre.

Boschma, R., \& Martin, R. (2010). The aims and scope of evolutionary economic geography. [Papers in Evolutionary Economic Geography \#10.01]. Utrecht University - Urban \& Regional Research Centre.

Bosma, N., \& Sternberg, R. (2014). Entrepreneurship s an urban event? Empirical evidence from European cities. Regional Studies, 48(6), 1016-1033.

Bresnahan, T., Gambardella, A., \& Saxenian, A. (2001). Old economy inputs for new economy outcomes: cluster formation in the new Silicon Valleys. Industrial and Corporate Change, 10(4), 835-860.

Brown, R., \& Mason, C. (2017). Looking inside the spiky bits: a critical review and conceptualization. Small Business Economics, 49(1), 11-30.

Bruns, K., Bosma, N., Sanders, M., \& Schramm, M. (2017). Searching for the existence of entrepreneurial ecosystems: a regional cross-section growth regression approach. Small Business Economics, 49(1), 31-54.

Cohen, B. (2006). Sustainable valley entrepreneurial ecosystems. Business Strategy and the Environment, 15(1), 1-14.

Crescenzi, R., \& Rodríguez-Pose, A. (2012). An integrated framework for the comparative analysis of the territorial innovation dynamics of developed and emerging countries. Journal of Economic Surveys, 26(3), 517-533.

Delgado, M., Porter, M., \& Stern, S. (2010). Clusters and entrepreneurship. Journal of Economic Geography, 10(4), 495-518.

Di Gregorio, D. \& Shane, S. (2003). Why do some universities generate more start-ups than others? Research Policy, 32(2), 209-227.

Dorfman, N. (1983). Route 128: the development of a regional high technology economy. Research Policy, 12(6), 299-316.

Duranton, G., \& Puga, D. (2002). Diversity and Specialisation in Cities: Why, Where and When Does It Matter? in P. McCann (ed.). Industrial Location Economics, Cheltenham: Edward Elgar, 151-186. 
Etzkowitz, H. (1998). The norms of entrepreneurial science: cognitive effects of the new universityindustry linkages. Research Policy, 27(8), 823-833.

Fagerberg, J., Mowery, D., \& Nelson, R. (eds) (2005). The Oxford Handbook of Innovation, Oxford: Oxford University Press.

Feld, B. (2012). Startup Communities: Building an Entrepreneurial Ecosystem in your City. Hoboken: John Wiley \& Sons.

Feldman, M. (2001). The entrepreneurial event revisited: firm formation in a regional context. Industrial and Corporate Change, 10(4), 861-881.

Feldman, M. (2014). The character of innovative places: entrepreneurial strategy, economic development, and prosperity. Small Business Economics, 43(1), 9-20.

Feldman, M., \& Lendel, I. (2011). The Emerging Industry Puzzle. Optics Unplugged', in H. Bathelt, M. P. Feldman, and D. F. Kogler (eds). Beyond Territory. Dynamic Geographies of Knowledge Creation, Diffusion, and Innovation, London and New York: Routledge, 107-148.

Fischer, B., Queiroz, S., \& Vonortas, N. (2018). On the location of knowledge-intensive entrepreneurship in developing countries: lessons from São Paulo, Brazil. Entrepreneurship and Regional Development (pre-print).

Fischer, B., Schaeffer, P., Vonortas, N., \& Queiroz, S. (2017). Quality Comes First: UniversityIndustry Collaboration as a Source of Academic Entrepreneurship in a Developing Country. Journal of Technology Transfer (pre-print).

Fitjar, R., \& Rodríguez-Pose, A. (2011). Innovating in the periphery: firms, values and innovation in Southwest Norway. European Planning Studies, 19(4), 555-574.

Florida, R. (2003). Cities and the creative class. City and Community, 2(1), 3-19.

Florida, R. (2005). The world is spiky: globalization has changed the economic playing field, but hasn't leveled it. Atlantic Monthly, 296(3), 48.

Florida, R., \& Mellander, C. (2014). Rise of the startup city: the changing geography of the venture capital financed innovation. [Working Paper n. 377]. Centre of Excellence for Science and Innovation Studies.

Fritsch, M. (2002). Measuring the quality of regional innovation systems: a knowledge production function approach. International Regional Science Review, 25(1), 86-101.

Gilbert, B., Audretsch, D., \& McDougall, P. (2004). The emergence of entrepreneurship policy. Small Business Economics, 22(3-4), 313-323.

Girma, S. (2005). Absorptive capacity and productivity spillovers from FDI: a threshold regression analysis. Oxford Bulletin of Economics and Statistics, 67(3), 281-306.

Glaeser, E., \& Kerr, W. (2009). Local industrial conditions and entrepreneurship: how much of the spatial distribution can we explain? Journal of Economics and Management Strategy, 18(3), 623-663.

Goertz, G. (2006). Assessing the trivialness, relevance, and relative importance of necessary or sufficient conditions in social science. Studies in Comparative International Development, 41(2), 88-109.

Guerrero, M., Urbano, D., Fayolle, A., Klofsten, M., \& Mian, S. (2016). Entrepreneurial universities: emerging models in the new social and economic landscape. Small Business Economics, 47(3), 551-563.

Guimón, J. (2009). Government strategies to attract R\&D intensive FDI. Journal of Technology Transfer, 34(4), 364-379.

Henderson, V. (2002). Urbanization in developing countries. The World Bank Research Observer, $17(1), 89-112$. 
Isaksen, A. (2016). Cluster emergence: combining pre-existing conditions and triggering factors. Entrepreneurship and Regional Development, 28(9-10), 704-723.

Isaksen, A., \& Trippl, M. (2017). Innovation in space: the mosaic of regional innovation patterns. Oxford Review of Economic Policy, 33(1), 122-140.

Isaksen, A., \& Trippl, M. (2016). Path Development in Different Regional Innovation Systems: A Conceptual Analysis', in M. D. Parrilli, R. D. Fitjar, and A. Rodriguez-Pose (eds). Innovation Drivers and Regional Innovation Strategies. London: Routledge, 66-84.

Isenberg, D. (2010). How to start an entrepreneurial revolution. Harvard Business Review, 88(6), 4051.

Lerner, J. (2002). When bureaucrats meet entrepreneurs: the design of effective public venture capital programmes. The Economic Journal, 112(477), F73-F84.

Mack, E., \& Mayer, H. (2016). The evolutionary dynamics of entrepreneurial ecosystems. Urban Studies, 53(10), 2118-2133.

Malecki, E. J. (2011). Connecting local entrepreneurial ecosystems to global innovation networks: Open innovation, double networks and knowledge integration. International Journal of Entrepreneurship and Innovation Management, 14, 36-59.

Martin, R., \& Sunley, P. (2003). Deconstructing clusters: chaotic concept or policy panacea? Journal of Economic Geography, 3(1), 5-35.

Martin, R.,\& Sunley, P. (2011). Conceptualizing cluster evolution: beyond the life cycle model? Regional Studies, 45(10), 1299-1318.

Mason, C., \& Brown, R. (2014). Entrepreneurial ecosystems and growth oriented entrepreneurship. Paris: Final Report to OECD http://lib.davender.com/wp-content/uploads/2015/03/ Entrepreneurial-ecosystems-OECD.pdf.

Motoyama, Y., \& Danley, B. (2012). An analysis of the geography of entrepreneurship: understanding the geographic trends of Inc. 500 companies over thirty years at the State and Metropolitan levels. [Report] Kauffman Foundation.

Motoyama, Y., \& Watkins, K. K. (2014). Examining the connections within the startup ecosystem: A case study of St. Louis [Research Series on City, Metro, and Regional Entrepreneurship]. Kauffman Foundation.

Neto, J., Farias Filho, J., \& Quelhas, O. (2014). Raising financial resources for small and medium enterprises: A multiple case study with Brazilian venture capital funds in the cities of Rio de Janeiro and São Paulo. International Journal of Innovation and Sustainable Development, 8(1), 77-91.

Nicotra, M., Romano, M., Giudice, M., \& Schillaci, C. (2017). The causal relation between entrepreneurial ecosystem and productive entrepreneurship: a measurement framework. Journal of Technology Transfer (pre-print).

Radosevic, S., \& Yoruk, E. (2013). Entrepreneurial propensity of innovation systems: theory, methodology and evidence. Research Policy, 42(5), 1015-1038.

Ragin, C. (2000). Fuzzy-set Social Science. Chicago: University of Chicago Press.

Ragin, C. C. (2006). Set relations in social research: Evaluating their consistency and coverage. Political Analysis, 14(3), 291-310.

Ragin, C. (2007). Fuzzy sets: calibration versus measurement. In J. M. Box-Steffensmeier, H. E. Brady \& D. Collier (Eds.). The Oxford Handbook of Political Methodology. Oxford: The Oxford University Press. 174-198.

Ragin, C. (2008). Redesigning social inquiry: Fuzzy sets and beyond. Chicago: University of Chicago Press. 
Ribeiro, L., \& Carvalho, A. (2008). Private equity and venture capital in an emerging economy: Evidence from Brazil. Venture Capital, 10(2), 111-126.

Rodríguez-Pose, A., \& Crescenzi, R. (2008). Mountains in a flat world: why proximity still matters for the location of economic activity. Cambridge Journal of Regions, Economy and Society, 1(3), 371-388.

Rosenthal, S., \& Strange, W. (2001). The determinants of agglomeration. Journal of Urban Economics, 50(2), 191-229.

Saxenian, A. (1994). Regional advantage: culture and competition in Silicon Valley and Route 128. Cambridge: Harvard University Press.

Schneider, M. R., Schulze-Bentrop, C., \& Paunescu, M. (2010). Mapping the institutional capital of high-tech firms: A fuzzy-set analysis of capitalist variety and export performance. Journal of International Business Studies, 41(2), 246-266.

Schneider, C. Q., \& Wagemann, C. (2012). Set-theoretic methods for the social sciences: A guide to qualitative comparative analysis. Cambridge: Cambridge University Press.

Spigel, B. (2017). The relational organization of entrepreneurial ecosystems. Entrepreneurship Theory and Practice, 41(1), 49-72.

Stam, E. (2009). Entrepreneurship, Evolution and Geography. [Papers in Evolutionary Economic Geography]. Utrecht University - Urban \& Regional Research Centre.

Stam, E. (2015). Entrepreneurial ecosystems and regional policy: a sympathetic critique. European Planning Studies, 23(9), 1759-1769.

Stam, E., \& Spigel, B. (2016). Entrepreneurial Ecosystems. [Discussion Paper Series n. 16-13]. Utrecht University - Utrecht School of Economics.

Storper, M. (1995). The resurgence of regional economies, ten years later the region as a nexus of untraded interdependencies. European Urban and Regional Studies, 2(3), 191-221.

Stuart, T., \& Sorenson, O. (2003). The geography of opportunity: spatial heterogeneity in founding rates and the performance of biotechnology firms. Research Policy, 32(2), 229-253.

WEF (2014). Entrepreneurial ecosystems around the globe and early-stage company growth dynamics: the entrepreneur's perspective. Geneva: World Economic Forum.

WEF (2018). These are the world's most innovative cities, and here's why. World Economic Forum. Available at: < https://www.weforum.org/agenda/2018/01/worlds-most-innovative-cities-j1l/>. Access in January, 2018.

\section{Appendix}

Quartiles used to calibrate fuzzy sets

\begin{tabular}{|c|c|c|c|c|c|c|c|c|c|c|c|}
\hline & PATENTS & HDI-M & KIJOBS & POPTOTAL & GDP & BUSCONC & PROXCAP & MNE-I & CRED & URB & ENERGY \\
\hline Valid & 298 & 299 & 299 & 299 & 299 & 297 & 114 & 65 & 284 & 299 & 299 \\
\hline Missing & 0 & 0 & 0 & 0 & 0 & 2 & 0 & 234 & 15 & 0 & 1 \\
\hline 25 & 0.0769 & 0.6120 & 0.000117 & $8,481.41$ & 110.93 & 0.000212 & 70.78 & 0.564 & $1,039.56$ & 0.7936 & 0.99245 \\
\hline 50 & 0.5384 & 0.6420 & 0.000307 & $29,270.18$ & 475.38 & 0.000749 & 143.50 & 3.0434 & $2,165.19$ & 0.9007 & 0.99635 \\
\hline 75 & 3.3846 & 0.6743 & 0.000528 & $78,658.00$ & $1,523.41$ & 0.001895 & 315.75 & 28.1608 & $3,524.51$ & 0.9603 & 0.9983 \\
\hline
\end{tabular}

